JBT, Volume-X, No-02, July-December, 2015

\title{
Time Management Behavior among Academic Procrastinators in Bangladesh: A Study on Undergraduate Students of Different Private Universities
}

\author{
ZANNATUL FERDUS* \\ THAWHIDUL KABIR ${ }^{* *}$ \\ SHIRIN AKTER ${ }^{* * *}$
}

\begin{abstract}
Procrastination and its impacts on students of various academic levels have been scrutinized for many years, but how the students involved in procrastination are utilizing their hours of a day have not been answered yet. To find out the answer, this study randomly sampled 1000 undergraduate private university students in Bangladesh and found that occasional procrastinators use most of their time for the academic purposes than non academic purposes if were judged against chronic and severe procrastinators. Moreover, it identified that, the academic results of the undergraduate students were negatively associated with their intensity of procrastination. Moreover, the amount of time they used for academic purpose was inversely inclined to their frequency of procrastination. On the contrary, this study also found that, the amount of time used by undergraduate students for non-academic purposes was positively associated with their extent procrastination.
\end{abstract}

Key words: Academic, Bangladesh, Private University, Procrastination, Undergraduate, Student

\section{INTRODUCTION}

Time is invaluable. Managing time efficiently may make people more effective in completing their compulsory tasks, and thus help individuals to avail

\footnotetext{
*Lecturer, Department of Management, Bangladesh University of Business and Technology, Dhaka Commerce College Road, Mirpur-2, Dhaka-1216.

${ }^{* *}$ Assistant Professor, Department of Management, Bangladesh University of Business and Technology, Dhaka Commerce College Road, Mirpur-2, Dhaka-1216.

*** Lecturer, Department of Management, Bangladesh University of Business and Technology, Dhaka Commerce College Road, Mirpur-2, Dhaka-1216.
} 
more time to spend on things which are important to them next to their occupational boundaries. In the academic context, effective time management is sturdily unavoidable for any one's successful academic career, especially for the university students whose lives are characterized by frequent deadlines of class texts, quiz tests, assignments and presentations etc. One's indifferent attitude towards effective time management may usually cause significant negative consequences in their future life. Earlier studies have regarded this unawareness among people about effective time management as an effect of procrastination which have been found to be a prevalent phenomenon in the general population (Blunt and Pychyl, 1998; Harriott and Ferrari, 1996), and most people strongly characterize it as being bad, harmful, and foolish (Briody, 1980).

Theoretically the term 'procrastination' refers to a complex psychological behavior among those people who are inclined with voluntary postponement towards an intended course of action despite expecting consequences resulting from that delay (Day, Mensink, and O'Sullivan 2000, Steel 2007). Hence, it has been frequently accused as one of the main causes of individuals' overall poor performance (Beswick, Rothblum, \& Mann, 1988; Steel, Brothen, \& Wambach, 2001; Wesley, 1994), misery in the long term (Knaus, 1973; Lay \& Schouwenburg, 1993; Tice \& Baumeister, 1997).Because of facing undesirable facts of life, over $95 \%$ of the procrastinators wish to reduce it (O'Brien, 2002). Different studies from various disciplines have envisaged the danger of procrastination. For example, in economics, Akerl of (1991) and O'Donoghue and Rabin (1999) considered the relative lack of retirement savings behavior as a form of procrastination, in which many start preparing for their later years far too late. Likewise, a survey by H\&R Block has indicated that procrastinating on taxes costs people on average $\$ 400$ because of rushing and consequent errors, resulting in over $\$ 473$ million in overpayments in 2002 (Kasper, 2004). In the political arena, procrastination has been used to describe both presidential decisions (Farnham, 1997; Kegley, 1989) and the banking practices of nations (Holland, 2001), in which important decisions are disastrously delayed. In the medical field, it have been commonly reported that, a major problem on the part of patients is procrastination (e.g., Morris, Menashe, Anderson, Malinow, \& Illingworth, 1990; White, Wearing, \& Hill, 1994; Bogg and Roberts, 2004). In the academic context, some of the recent studies have found procrastination as a commonly occurring phenomenon among undergraduate students (Day et al. 2000, Klassen, Krawchuk, and Rajani 2008) and the study conducted by Tice and Baumeister (1997) reported that university students who rated high on procrastination not only received low grades but also reported a high level of stress along with poor self-rated health. Based on the aforesaid grounds, this study informatively assumes procrastination as one of the main obstacles for 
students' successful academic career and hence, due to the importance of studying the nature of time management behavior among procrastinating students, this study primarily aims to discover how students are managing their time who are highly involved in procrastination, that is, on which purpose they use to spend the 24 hours of a day.

\section{LITERATURE REVIEW}

\section{Procrastination and its Types}

Procrastination is not a neutral or innocuous form of time management (Tice \& Baumeister, 1997, p. 456) but a complex process that involves affective, cognitive, and behavioral components (Fee \& Tangney, 2000) which implies that, to procrastinate is "to voluntarily delay an intended course of action despite expecting to be worse-off for the delay" (Ellis \& Knaus, 1977; Knaus, 2000; Steel, 2007). In contrast to this common cognition, Chase (2003), a management skills consultant, have accentuated that procrastination is the "new master skill of time management', and further have added that, it is a behavioral approach of making sure that the right items are procrastinated by knowing how to select between what gets put off and what must be done on time (Chase, 2003, p.60). Likewise, Chu \& Choi (2005) in their study have told apart that, not all procrastination behaviors either are harmful or lead to negative consequences, and thus, they have theorized that there are two types of procrastinators, namely: passive procrastinators and active procrastinators. According to Chu \& Choi (2005), passive procrastinators are procrastinators in the traditional sense who are paralyzed by their indecision to act and fail to complete tasks on time; and active procrastinators are a 'positive' type of procrastinator who prefer to work under pressure, and make deliberate decisions to procrastinate (Chu \& Choi, 2005). Later, Tucker-Ladd (2006) classified procrastinating behavior among people into two types: the relaxed type who may have negative feelings towards work (but not socialization), and (b) the anxious type who is worried about such issues as pressure, ability and fear of failure.

\section{Causes of Procrastination among People}

As an explanation of procrastination, Tice et al.'s (2004)work shows that when individuals think doing something immediately will make them 'feel' better, they opt for the small reward now rather than the larger reward later, and thus, procrastination is often caused by the immediate desire/need to make oneself 'feel better'. From another standpoint, Cook (1999) has explained that someone procrastinate because they simply do not want to do the job because of the fear of failure, lack of adequate information for the task, or bad habits. 
Moreover, it has been found in other studies that individuals who procrastinate use self-handicapping as a means of self-protection (Beck, Koons, \&Milgrim 2000, Fee \& Tangney 2000, Ferrari \& Tice 2000). In the same way, several quantitative studies have significantly correlated procrastination with measures of depression, irrational cognitions, low self-esteem, delayed study behavior, anxiety, and lack of assertion (Fee \& Tangney 2000, Solomon \&Rothblum 1984). In addition to this, Steel (2007) found task evasiveness, task delay, self-efficacy, impulsiveness, and conscientiousness as strong predictors of procrastination.

\section{Frequency and the Impact of Procrastination on Students}

In the pasture of academic environment, procrastination on academic tasks is a common problem among students (Day, Mensink, \& O'Sullivan, 2000; Schouwenburg, 1995; Solomon \& Rothblum, 1984; Wolters, 2003). Studies have disclosed that 50 to $95 \%$ of students procrastinate (Ellis \&Knauss, 1977; O'Brien, 2002; Solomon \&Rothblum, 1984) and $32 \%$ of students had severe problems with procrastination while other students had procrastination-related issues impacting on their studies (Day, Mensink \& O'Sullivan, 2000) and procrastination commonly affects $46 \%$ to $95 \%$ of students (Gallagher, Borg, Golin, \& Kellehr, 1992; Janssen \& Carton, 1999; Kachgal, Hansen, \& Nutter, 2001; Paden \& Stell, 1997; Özer, Demir, \& Ferrari, 2009). However, a substantial body of literature has shown a negative association between procrastination and academic performance (Akinsola, Tella, \& Tella, 2007; Beck, Koons, \& Milgrim, 2000; Elvers, Polzella, \& Graetz, 2003; Moon \& Illingworth, 2005; Orpen, 1998; Tice \& Baumeister, 1997; Wang \& Englander, 2010). As well, procrastination has been linked to other adverse behavior and outcomes including poor study habits, test anxiety, cramming for examinations, late submission of course work, fear of failure, fear of social disapproval by peers, lower grades, sense of guilt, and depression (Clark \& Hill, 1994; Dewitte \& Schouwenburg, 2002; Ferrari \& Scher, 2000; Fritzsche, Young, \& Hickson, 2003; Lay \& Schouwenburg, 1993; Lee, 2005; Midgley \& Urdan, 2001; Uzun Ozer, Demir, \& Ferrari, 2009). However, there is also evidence to suggest that some students use procrastination strategically to help them juggle multiple responsibilities (Sokolowska \& Zusho, 2006) or to offset negative emotions related to upcoming deadlines (Tice \& Baumeister, 1997).

\section{Time Management and its Predictors}

Time management has been described using many different terms including spontaneity, balance, flexibility, and having control over time (Lakein, 1973). Time management has been considered as the process by which an individual more effectively accomplishes tasks and goals (Schuler, 1979) or a process by which an individual obtains control over the timing and the content of what can 
be accomplished with time (Mackenzie, 1972, 1975, 1990). An individual will become effective in using their time only when the individual clearly knows what they want to do, what they need to do, and for which specific target date (Soucie, 1986). More elaborately, according to Crutsinger (1994), time management involves determining what one should do by setting goals, deciding which events are the most important and realizing that other activities will have to be scheduled around them (prioritizing), making decisions about how much time to allow for certain tasks (time estimation), adjusting to the unexpected (problem solving), reconsidering goals and priorities on a regular basis (evaluation), and observing patterns and trends in behavior. Thus, in the literature, time management behavior is frequently referred to the behavior of setting goals and priorities, engaging in the mechanics of time management, and having a preference for organization (Adams and Jex, 1999; Macan, 1994, 1996; Macan et al., 1990) and hence, seven time management skills or behaviors have been considered essential to effective time management due to their repetitive prominence in the literature: (a) time analysis, (b) planning, (c) goal setting, (d) prioritizing, (e) scheduling, (f) organizing, and (g) establishing new and improved time habits (Hellsten \& Rogers, 2009; Lakein, 1973; Mackenzie, 1972, 1975, 1990; Morris, 2001; Woolfolk \& Woolfolk, 1986). The results of the review of time management show that the effective use of time has long been recognized as a crucial factor for success in many different fields and many practical techniques have been devised for improving time management (Puffer, 1989). Given the widespread use and acceptance of the value of time management behaviors (Jex \& Elacqua, 1999), it is unfortunate that only a modest amount of empirical research has been conducted. In general, results from empirical studies have shown that self-reports of time management is related to academic achievement, age, and gender (Britton \& Tesser, 1991; Lahmers \& Zulauf, 2000; Simons \& Galotti, 1992), good time managers appear to prefer planning and organization (Williams et al., 1995), and individuals who have previous time management training also appear to engage more frequently in time management behaviors (Britton \& Tesser, 1991; Hellsten \& Rogers, 2009; Macan, 1994; 1996; Macan et al., 1990; Simons \& Galotti, 1992; Williams et al., 1995; Woolfolk \& Woolfolk, 1986).

\section{Relationship between Students' Extent of Procrastination and Time Management}

Dipboye and Phillips (1990) have shown in their study that university students who had more sense of purpose and structure in their use of time reported greater psychological well-being and more efficient habits of study, and from a another angle, Lay (1990) have found passive procrastinators to 
underestimate the overall time that was required to complete tasks. Afterward, Lay and Schouwenburg (1993) have studied the relation between trait procrastination and time management and thus, they have found that, people high on trait procrastination exhibited a greater likelihood of being behind schedule on their personal projects, studying fewer hours than intended for an examination, low scores on feeling in control of time, setting goals and priorities, and consequently, often fail to complete tasks on time, triggering the perception of reduced control of time and use fewer time management techniques (Lay \& Schouwenburg, 1993). Vodanovich and Seib (1997), also have concluded with same result, that is, procrastinators tend to have weak, if any, structure in their time use, and Van Eerde (2003) have evidently suggested that time management training significantly increases time management behaviors and decreases trait procrastination.

\section{Research Gap and Specific Objectives}

This study has found, from the aforementioned review of literature that, no study, either on procrastination or on time management, previously had scrutinized how time is being managed by the students who procrastinate. Since there is a scope for further exploration, this study had adopted a conclusive design in order to explore academic procrastination more deeply and hence, had focused on the affective consequences to handle the effects academic procrastination among the undergraduate students of business studying in different private universities in Bangladesh. This study has specified its aim to assess the frequency of procrastination and its impact on the results of students along with their time management behavior.

\section{THEORETICAL FRAMEWORK}

\section{Frequency of Academic Procrastination}

This study has defined academic procrastination among students as their deliberate tendency of delaying compulsory tasks and it is the dependent variable of this study. Thus, the frequency of procrastination among students was measured by using the 10-item procrastination scale developed by Florey (2000) which classifies academic procrastinators into three types, namely, Occasional Procrastinators, Chronic Procrastinators and Severe Procrastinators.

\section{Time Management Behavior}

Time management behavior has been considered as the dependent variable in this study and consequently, the time management among the undergraduate students in this study has been conceived as a behavioral construct which influences students' rationality of allocating time into different purposes. Thus, 
this study has assumed that, under the regular circumstances, most of the undergraduate business students utilize 24 hours of a day on 'Academic Purpose' which includes attending class lectures, conducting group-study and self-study; 'Sustenance Purpose' which includes having food and sleep; 'Socialization Purpose' which includes passing time with friends and family members; and all other remaining things were synchronized and totalled as well into the 'Miscellaneous Purpose'.

\section{Research Hypotheses}

Based on the theoretical scope and the available findings from the literature, this study has hypothesized that,

$\mathrm{H}_{1}$ : Procrastination will have negative impact on the achieved results of the undergraduate students of different private universities in Bangladesh.

$\mathrm{H}_{2}$ : A higher level of procrastination will reduces students' apportioned time for attending class lectures and group studies.

$\mathrm{H}_{3}$ : Students' higher level of procrastination reduces their apportioned time for self-study.

$\mathrm{H}_{4}$ : Students' higher level of procrastination will increase their apportioned time of involvement in sustenance, socialization and other purposes.

\section{METHODOLOGY OF THE STUDY}

\section{Research Design}

The general objective of this study was to identify the impact of procrastination on the time management behavior among the undergraduate business students from different private universities in Bangladesh and hence, the most appropriate type of research design for this study was causal research design. It is because, in accordance with Malhotra (2009 p. 246), causal research is "a type of conclusive research where the major objective is to obtain evidence regarding cause-and-effect (causal) relationships".

\section{Operationalization}

As mentioned earlier, to measure the frequency of procrastination among students this study had adopted the 10-item procrastination scale developed by Florey (2000). Consequently, feedback of respondents had been taken on each of those 10 items by using the four point likert scale technique where a score of 01 means 'Strongly Disagree', 02 means 'Disagree', 03 means 'Agree' and 04 means 'Strongly Agree'. Based on the assembled responses, the procrastination 
quotient for each respondent had been calculated which ranges from 0 to 40 , and then they were classified into three different categories, namely: Occasional Procrastinators (who scored 20 and below), Chronic Procrastinators (who scored more than 21 to below 30) and Severe Procrastinators (who above 30). Besides, as it had been theorized in this study, a constant sum scaling technique is used the measure the time management behavior of students and hence, they were asked to allocate the 24 hours of a day corresponding to their habitual time consumption for the purpose of attending class lectures, conducting group and self study; passing quality time with friends and family members; taking food and sleeping; and for other purposes.

\section{Sampling and Data Collection Technique}

To achieve the objectives of this study, more or less a sampling technique was used and consequently, a total of 1000 undergraduate students from different private universities operating in Dhaka metropolitan city, Bangladesh, were surveyed by questionnaire.

\section{Data Analysis Technique}

Parametric statistical analysis techniques were used to assess and measure different major issues of this study. More specifically, 'Chronbach's Alpha' value was assessed to measure the reliability of the collected data, and frequency distribution was calculated to know the extent of procrastination and time management behavior among students. Additionally, the 'Bivariate' correlation analysis was done by using 'Pearson Product-moment Correlation' technique to explore the impacts of procrastination on time management behavior of students. Consequently, to interpret the influences identified by correlation analysis, this study had considered the standards suggested by Cohen (1988) where ' $\mathrm{r}=.10$ to .29 or $r=-.10$ to -.29 ' stands for 'weak'; ' $r=.30$ to .49 or $r=-.30$ to -.49 ' for 'medium' and ' $\mathrm{r}=.50$ to 1.0 or $\mathrm{r}=-.50$ to -1.0 ' for 'strong' relationships.

\section{FINDINGS AND DISCUSSIONS}

\section{Sample Demographics}

Out of 1000 received feedback, after rejecting 103 incomplete questionnaires, a total of 897 feedbacks was finally retained which engendered $89.70 \%$ response rate for this study where $53 \%$ of them were male and $47 \%$ were female students (see Table 01 below). 
TABLE 01

SAMPLE DEMOGRAPHICS

\begin{tabular}{lcc}
\hline \multicolumn{1}{c|}{ Particulars } & Frequency & Percent \\
\hline Gender & & \\
Male & 475 & 53.0 \\
Female & 422 & 47.0 \\
Total & 897 & 100.0 \\
Academic Results & & \\
Below Average Students (SGPA 01.00-1.99) & 14 & 1.6 \\
Average(SGPA 02.00 - 02.99) & 127 & 14.2 \\
Above Average Students(SGPA 03.00 - 04.00) & 756 & 84.3 \\
Total & 897 & 100.0 \\
Frequency of Procrastination & & \\
Occasional Procrastinators & 433 & 48.3 \\
Chronic Procrastinators & 400 & 44.6 \\
Severe Procrastinators & 64 & 7.1 \\
Total & 897 & 100.0 \\
\hline
\end{tabular}

In addition, from the Table 01 above, it can be observed that, majority (84.3\%) of the sampled 897 students were above average students who had achieved their SGPA between 03.00 to 04.00. In case of the frequency of procrastination among students, it also can be seen from the same Table that, only 64 students $(7.1 \%)$ were the severe procrastinators, $44.6 \%$ were chronic procrastinators and majority $(48.3 \%)$ were occasional procrastinators.

\section{Reliability Analysis}

Table 02 below shows the reliability statistics of the scales used in this study. It can seen from the Table 02 below that the reported values of 'Cronbach Alpha' for each scale used in this study was good where overall alpha value reported was in a range between 0.618 to 0.928 indicating an acceptable level of internal consistency of the collected data. 
TABLE 02

RELIABILITY STATISTICS

\begin{tabular}{l|c}
\hline \multicolumn{1}{c|}{$\quad$ Particulars } & \multicolumn{1}{c}{$\begin{array}{c}\text { Value of } \\
\text { Cronbach's Alpha }\end{array}$} \\
\hline $\begin{array}{l}\text { 10-Item procrastination scale } \\
\text { Time used for academic purpose }\end{array}$ & 0.928 \\
\# Attending class lectures & \\
\# Participating in group study & 0.618 \\
\# Conducting self study & \\
Time Used For Sustenance Purpose & \\
\# Taking food & \\
\# Sleeping & \\
Time used for socialization purpose & \\
\# Passing time with family members & \\
\# Passing time with friends & \\
Time used for other purposes & 0.821 \\
\hline
\end{tabular}

\section{Time Management Behavior among Procrastinators}

Table 03 below shows the time use pattern by gender, type of procrastination and academic results of the procrastinating undergraduate students. From table 03 , it can be found that, average to above average male students who were chronic procrastinators had used 4.15 hours for studying which was $15 \%$ more than severe procrastinators. In regard of gender, chronic male procrastinators spent more time in studying than female procrastinators which was $3 \%$ and severe female procrastinators had used $6 \%$ more time than severs male procrastinators. In attending class lecture and group studying, average to above average male students who were chronic procrastinators had used 3.64 hours which was $48 \%$ more than severe procrastinators, whereas female students who were chronic procrastinators had used $43 \%$ more time than severe procrastinators in attending class lecture and group study. In comparison with male and female procrastinators, chronic procrastinator male students were spending 9\% more time than female and severe procrastinator male students were spending $3 \%$ more time in class lecture and group study than female procrastinator students. Severe procrastinator male students were spending $4 \%$ more time in gossiping with friends and family members than the chronic procrastinator male students. Severe procrastinator female students also spent $10 \%$ more time in context of chronic procrastinator female students in gossiping with friends and family members. In judgement between male and female procrastinator students, chronic male procrastinator students were spending $2 \%$ and severe procrastinator female students were spending 5\% more time than each other. In taking food, both severe male and female procrastinator students spent equal quantity of time. 
Severe male procrastinator students spent more time by sleeping than female procrastinator students which was $4 \%$. Average to above average students who were severe male procrastinators had used 4.00 hours for other purposes which was $38 \%$ more than chronic, where severe female procrastinators spent $40 \%$ of their time for other purposes.

On other hand, it has also been found that, above average students who were occasional procrastinators had used 5.55 hours for studying which was $12 \%$ more than chronic and $24 \%$ more the severe procrastinators. In concerning gender, there was a significant difference between severe male and female procrastinators than other criterion and that was $13 \%$. In attending class lecture and group studying, all types of procrastinators' of above average cluster spent more or less same time. Severe procrastinators male students were spending 4.00 hours in gossiping with friends and family members which was $23 \%$ more than severe procrastinators female students. In taking food and sleeping all types of procrastinators' of above average both male and female spent almost equal time rather than severe male and female procrastinators, the difference was $6 \%$.Severe female procrastinator's students used $25 \%$ of their time in other purpose than the other types of procrastinator.

By and large, it can be seen in the Table 03 that, both male and female procrastinators with below to average and above average results used to spend their more time on non-academic purposes than academic purposes.

TABLE 03

PROCRASTINATORS AVERAGE USE OF HOURS

\begin{tabular}{|c|c|c|c|c|c|c|c|}
\hline \multirow{5}{*}{$\begin{array}{l}\text { Type of } \\
\text { Students }\end{array}$} & \multirow[t]{5}{*}{ Purposes } & \multicolumn{6}{|c|}{ Gender of the Respondents } \\
\hline & & \multicolumn{3}{|c|}{ Male } & \multicolumn{3}{|c|}{ Female } \\
\hline & & \multicolumn{3}{|c|}{ Type of Procrastinators } & \multicolumn{3}{|c|}{ Type of Procrastinators } \\
\hline & & Occasional & Chronic & Severe & Occasional & Chronic & Severe \\
\hline & & Mean & Mean & Mean & Mean & Mean & Mean \\
\hline \multirow{3}{*}{$\begin{array}{l}\text { Below } \\
\text { Average } \\
\text { to } \\
\text { Average }\end{array}$} & $\begin{array}{l}\text { Involvement in } \\
\text { Self Study }\end{array}$ & - & 4.15 & 3.61 & - & 4.04 & 3.84 \\
\hline & $\begin{array}{l}\text { Attending Class } \\
\text { Lecture and } \\
\text { Group Study }\end{array}$ & - & 3.64 & 1.75 & - & 3.98 & 1.70 \\
\hline & $\begin{array}{l}\text { Gossiping with } \\
\text { Friends and } \\
\text { Family Members }\end{array}$ & - & 2.71 & 2.82 & - & 2.66 & 2.96 \\
\hline
\end{tabular}




\begin{tabular}{|c|c|c|c|c|c|c|c|}
\hline \multirow{8}{*}{$\begin{array}{l}\text { Type of } \\
\text { Students }\end{array}$} & \multirow[t]{5}{*}{ Purposes } & \multicolumn{6}{|c|}{ Gender of the Respondents } \\
\hline & & \multicolumn{3}{|c|}{ Male } & \multicolumn{3}{|c|}{ Female } \\
\hline & & \multicolumn{3}{|c|}{ Type of Procrastinators } & \multicolumn{3}{|c|}{ Type of Procrastinators } \\
\hline & & Occasional & Chronic & Severe & Occasional & Chronic & Severe \\
\hline & & Mean & Mean & Mean & Mean & Mean & Mean \\
\hline & $\begin{array}{l}\text { Time Spent in } \\
\text { Taking Foods } \\
\text { (Including } \\
\text { breakfast, lunch, } \\
\text { dinner and } \\
\text { snacks etc.) }\end{array}$ & - & 2.99 & 3.44 & - & 2.95 & 3.44 \\
\hline & $\begin{array}{l}\text { Time Spent by } \\
\text { Sleeping }\end{array}$ & - & 7.62 & 8.38 & - & 7.60 & 8.08 \\
\hline & $\begin{array}{l}\text { Time Spent in } \\
\text { Other Purposes }\end{array}$ & - & 2.89 & 4.00 & - & 2.77 & 3.98 \\
\hline Total & & - & 24.00 & 24.00 & - & 24.00 & 24.00 \\
\hline \multirow[t]{6}{*}{$\begin{array}{l}\text { Above } \\
\text { Average }\end{array}$} & $\begin{array}{l}\text { Involvement in } \\
\text { Self Study }\end{array}$ & 5.55 & 4.94 & 4.00 & 5.59 & 5.01 & 4.50 \\
\hline & $\begin{array}{l}\text { Attending Class } \\
\text { Lecture and } \\
\text { Group Study }\end{array}$ & 6.36 & 4.36 & 2.00 & 6.33 & 4.37 & 2.00 \\
\hline & $\begin{array}{l}\text { Gossiping with } \\
\text { Friends and } \\
\text { Family Members }\end{array}$ & 1.70 & 2.31 & 4.00 & 1.71 & 2.30 & 3.25 \\
\hline & $\begin{array}{l}\text { Time Spent in } \\
\text { Taking Foods } \\
\text { (Including } \\
\text { breakfast, lunch, } \\
\text { dinner and } \\
\text { snacks etc.) }\end{array}$ & 2.34 & 2.69 & 3.00 & 2.34 & 2.71 & 3.00 \\
\hline & $\begin{array}{l}\text { Time Spent by } \\
\text { Sleeping }\end{array}$ & 6.36 & 7.05 & 8.00 & 6.35 & 7.02 & 7.50 \\
\hline & $\begin{array}{l}\text { Time Spent in } \\
\text { Other Purposes }\end{array}$ & 1.69 & 2.65 & 3.00 & 1.68 & 2.59 & 3.75 \\
\hline Total & & 24.00 & 24.00 & 24.00 & 24.00 & 24.00 & 24.00 \\
\hline
\end{tabular}

\section{Impacts of Procrastination on Results}

Table 04 below depicts the impact of procrastination on students' result. From Table 04, it can be observed that correlation coefficients of the two independent variables, frequency of procrastination with $r=-0.852$ and types of procrastinators with $r=-0.760$, had demonstrated strong and inverse relationship with the dependent variable, students' results, significantly (in both cases, $\alpha=$ $<0.05)$. It can be generalized from the findings illustrated in Table 04 that, procrastinating tendency among the undergraduate students had a significantly 
inverse relationship with their achieved results in the context of Bangladesh which had proved that, the more an undergraduate student procrastinated the more that student had suffered from negative consequence caused by it. Thus, this study found strong evidence in the favor of $\mathbf{H}_{\mathbf{1}}$ in the context of Bangladesh.

TABLE 04

\section{IMPACT OF PROCRASTINATION ON ACADEMIC RESULT}

\begin{tabular}{l|c|c|c}
\hline \multicolumn{1}{c}{$\begin{array}{c}\text { Correlation } \\
\text { Coefficients }\end{array}$} & $\begin{array}{c}\text { Students' } \\
\text { Result }\end{array}$ & $\begin{array}{c}\text { Frequency of } \\
\text { Procrastination }\end{array}$ & $\begin{array}{c}\text { Type of } \\
\text { Procrastinators }\end{array}$ \\
\hline Students' Results & 1 & & \\
Frequency of Procrastination & $-.852^{* *}$ & 1 & 1 \\
Type of Procrastinators & $-.760^{* *}$ & $.892^{* *}$ & \\
${ }^{* * *}$ Correlation is significant at the 0.01 level (1-tailed). &
\end{tabular}

\section{Relationship between of Procrastination and Time Management Behavior}

Table 05 below envisages how frequency of procrastination influences students' time management behavior. From the Table 05, it can be observed that a higher frequency of procrastination had a significantly strong and inverse relationship with students' use of average quantity of time for self-studying purpose (with $r=-0.768$ and $\alpha=<0.05$ ), and class-attending and group-studying purpose (with $\mathrm{r}=-0.939$ and $\alpha=<0.05$ ). This means, higher level of procrastination negatively influences the undergraduate students' time management behavior for academic purposes and hence, these findings provided a strong support in favor of predefined hypotheses, $\mathbf{H}_{\mathbf{2}}$ and $\mathbf{H}_{3}$. Besides, it also had been found in this study that, as shown in Table 05, higher degree of procrastination had significantly positive association with students' use of average quantity of time for passing quality times with friends and family members (with $r=0.636$ and $\alpha=<0.05$ ), for taking food (with $r=0.785$ and $\alpha=$ $<0.05$ ), for sleeping (with $r=0.897$ and $\alpha=<0.05$ ) and for other purposes (with $r$ $=0.796$ and $\alpha=<0.05$ ). Which altogether means that, the more a student was involved in higher degree of procrastination, the more quantity of time that student had spent for non-academic purposes and thus, strongly supported $\mathbf{H}_{4}$. 
TABLE 05

IMPACT OF PROCRASTINATION ON STUDENTS TIME MANAGEMENT BEHAVIOR

\begin{tabular}{|c|c|c|c|c|c|c|c|}
\hline & $\begin{array}{l}\text { Frequency } \\
\text { of } \\
\text { Procrastin } \\
\text { ation }\end{array}$ & $\begin{array}{c}\text { Hours } \\
\text { Spent For } \\
\text { Self } \\
\text { Studying }\end{array}$ & $\begin{array}{l}\text { Hours } \\
\text { spent for } \\
\text { Attending } \\
\text { Class } \\
\text { Lectures } \\
\text { and group } \\
\text { studies }\end{array}$ & $\begin{array}{c}\text { Hours } \\
\text { spent with } \\
\text { friends } \\
\text { and family } \\
\text { members }\end{array}$ & $\begin{array}{l}\text { Hours } \\
\text { spent for } \\
\text { taking } \\
\text { foods }\end{array}$ & $\begin{array}{l}\text { Hours } \\
\text { spent by } \\
\text { sleeping }\end{array}$ & $\begin{array}{l}\text { Hours } \\
\text { spent on } \\
\text { other } \\
\text { purposes }\end{array}$ \\
\hline $\begin{array}{l}\text { Frequency } \\
\text { of } \\
\text { Procrastin } \\
\text { ation }\end{array}$ & 1 & & & & & & \\
\hline $\begin{array}{l}\text { Hours } \\
\text { Spent For } \\
\text { Self } \\
\text { Studying }\end{array}$ & $-.768^{* *}$ & 1 & & & & & \\
\hline $\begin{array}{l}\text { Hours } \\
\text { spent for } \\
\text { Attending } \\
\text { Class } \\
\text { Lectures } \\
\text { and group } \\
\text { studies }\end{array}$ & $-.939^{* *}$ & $.561^{* *}$ & 1 & & & & \\
\hline $\begin{array}{l}\text { Hours } \\
\text { spent with } \\
\text { friends } \\
\text { and family } \\
\text { members }\end{array}$ & $.636^{* *}$ & $-.494^{* *}$ & $-.649^{* *}$ & 1 & & & \\
\hline $\begin{array}{l}\text { Hours } \\
\text { spent for } \\
\text { taking } \\
\text { foods }\end{array}$ & $.785^{* *}$ & $-.602^{* *}$ & $-.779^{* *}$ & $.438^{* *}$ & 1 & & \\
\hline $\begin{array}{l}\text { Hours } \\
\text { spent by } \\
\text { sleeping }\end{array}$ & $.897^{* *}$ & $-.763^{* *}$ & $-.849^{* *}$ & $.517^{* *}$ & $.757^{* *}$ & 1 & \\
\hline $\begin{array}{l}\text { Hours } \\
\text { spent on } \\
\text { other } \\
\text { purposes }\end{array}$ & $.796^{* *}$ & $-.629^{* *}$ & $-.748^{* * *}$ & $.182^{* *}$ & $.526^{* *}$ & $.665^{* *}$ & 1 \\
\hline
\end{tabular}




\section{CONCLUSION}

It is an eternal truth that, both time and students are too far valuable asset to waste. For an over-populated country like Bangladesh, inefficient students are burdens both for their families and the society where they belong. Moreover, inefficiency of time management among students endangers their academic careers and consequently may convert them into an ineffective workforce for a nation. Hence, this study conclusively suggests its stakeholders based on the findings that proper remedial strategies should be adopted as early as possible. It will mitigate the tendency of procrastination among undergraduate students. Besides, more studies should be conducted to know about the procrastination tendency and its impacts on students academic career in different types of regular, vocational and community schools, colleges and institutions, so that, it could be possible to know where the future of this country is moving ahead.

\section{REFERENCES}

A.Blunt, A. T. Pychyl: "Volitional action and inaction in the lives of undergraduate students: State orientation, procrastination and proneness to boredom"Personality Individual Difference, 24,pp837-846.(1998)

J. Harriott,J. Ferrari: Prevalence of procrastination among samples of adults.Psychological Reports, 611-616.(1996)

R. Briody: "An exploratory study of procrastination (Doctoral dissertation, Brandeis University)" Dissertation Abstracts International,41, 590.(1980)

V. Day, D.Mensink, and M. O'Sullivan:"Patterns of academic procrastination'Journal of College Reading and Learning, 30, pp 120-134. (2000).

P. Steel:"The nature of procrastination: A meta-analytic and theoretical review of quintessential self-regulatoryfailure"Psychological Bulletin, 133 (1), pp 6594.(2007)

G. Beswick, D. E. Rothblum and L. Mann: "Psychological antecedents of student procrastination" Australian Psychologist, 23, pp207-217. (1988)

P. Steel, T. Brothen, and C. Wambach: "Procrastination and personality, performance, and mood" Personality and Individual Differences,30,pp95-106. (2001)

C. J. Wesley:"Effects of ability, high school achievement, and procrastinatorybehavior on college performance" Educational and Psychological Measurement, 54, pp404408. (1994)

W. J. Knaus: "Overcoming procrastination" Rational Living, 8(2), pp2-7. (1973)

C. H. Lay, H.C. Schouwenburg: "Trait procrastination, time management, and academic behavior" Journal of Social Behavior and Personality, 8,pp647-662. (1993) 
D. M. Tice, R. F. Baumeister: "Longitudinal study of procrastination, performance, stress, and health: The costs and benefits of dawdling"Psychological Science, $\mathbf{8}$, pp454-458.(1997)

W. K. O'Brien: Applying the transtheoretical model to academic procrastination. Unpublished doctoral dissertation, University of Houston. (2002)

R. L. Fee, J. P. Tangney:“Procrastination: A means of avoiding shame or guilt?” J. R. Ferrari and T.A. Pychyl : (eds.)"Procrastination: Current Issues and New Directions [Special Issue]"Journal of Social Behavior and Personality, 15 (5): pp167-184.(2000)

G. A. Akerlof: "Procrastination and obedience" American Economic Review, 81(2),pp 119. (1991)

T. O'Donoghue and M. Rabin: “Incentives for procrastinators" Quarterly Journal of Economics, 114,pp769-816. (1999)

G. Kasper: "Tax procrastination: Survey finds $29 \%$ have yet to begin taxes"Retrieved March 14, 20013, from http://www.prweb.com/releases/2004/3/prweb114250. htm. (2004)

B. R. Farnham: "Roosevelt and the Munich crisis: A study of political decision-making" Princeton, NJ: Princeton University Press. (1997)

C. W. Kegley: "The Bush administration and the future of American foreign policy: Pragmatism, or procrastination?"Presidential Studies Quarterly,19,pp717731.(1989)

T. Holland: "The perils of procrastination" Far Eastern Economic Review, 164,pp66-72. (2001)

C. D. Morris et al.: "Community cholesterol screening: Medicalfollow-up in subjects identified with high plasma cholesterol levels" Preventative Medicine, 19, pp493-501. (1990)

V. M. White, A. J. Wearing and D. J. Hill: "Is the conflict model of decision making applicable to the decision to be screened for cervical cancer? A field study" Journal of Behavioral Decision Making, 7,pp57-72. (1994)

T. Bogg, B. W. Roberts:"Conscientiousness and health-related behaviors: A metaanalysis of the leading behavioral contributors tomortality." Psychological Bulletin, 130,pp887-919.(2004)

R. M. Klassen, L. L. Krawchuck and S. Rajani: "Academic procrastination of undergraduates: Low self-efficacy to self-regulate predicts higher levels of procrastination"Contemporary Educational Psychology,33, pp915-931. (2008)

A. Ellis, W. J. Knaus:Overcoming procrastination. New York: Signet. (1977) 
W. J. Knaus: "Procrastination, blame, and change"Journal of Social Behavior and Personality, 15, pp153-166. (2000)

L. Chase: "Procrastination: the new master skill of time management" Agency Sales Magazine, 33, pp60-62. (2003)

A. H. Chu, J. N Choi:"Rethinking procrastination: Positive effects of "active" procrastination on attitudes and performance"Journal of Social Psychology, Retrieved from High Beam database. (2005)

C. Tucker-Ladd: Psychological self-help, (Chapter 4: Behaviour motivation and selfcontrol) viewed 2 March 20013, http://www.psychologicalselfhelp.org/ (2006).

D. M. Tice, R. F. Baumeister andL. Zhang:"The role of emotion in self-regulation: Differing role of positive and negative emotions" In: Philippot P, Feldman RS, (eds.) "The regulation of emotion"Mahwah,NJ: USum Associates, pp 213226.(2004)

M. Cook:Streetwise Time Management, Avon: Adams Media Corporation. (1999)

B.L. Beck, S. R. Koons, and D. L. Milgrim: "Correlates and consequences of behavioral procrastination: The effects of academic procrastination, self-consciousness, self-esteem, and self-handicapping"J. R. Ferrari, T. A. Pychyl: (eds.) "Procrastination: Current Issues and New Directions [Special Issue]"Journal of Social Behavior and Personality, 15 (5), pp167-184. (2000)

J. R. Ferrari, D. M Tice:"Procrastination as a self-handicap for men and women: A task avoidance strategy in a laboratory setting"Journal of Research in Personality,34, pp 73-83.(2000)

H. Schouwenburg: "Academic procrastination: Theoretical notions, measurement, and research" In J. R. Ferrari and J.L. Johnson (Eds.), Procrastination and task avoidance: Theory, research, and treatment, New York: Plenum Press, pp. 7196. (1995)

L. J. Solomon, E. D. Rothblum: "Academic procrastination: Frequency and cognitivebehavioral correlates" Journal of Counseling Psychology, 31, pp503-509.(1984)

C.A. Wolters: "Understanding procrastination from a self-regulated learning perspective" Journal of Educational Psychology, 95, pp 179-187. (2003)

R.P. Gallagher, S. Borg, A. Golin, K. Kelleher: "The personal, career, and learning skills needs of college students" Journal of College Student Development, 33(4), pp 301-10. (1992)

T. Janssen, J. S. Carton: "The effects of locus of control and task difficulty on procrastination" Journal of Genetic Psychology, 160(4), 436-442. (1999) 
M. Kachgal, L. S. Hansen, K. J. Nutter: “Academic procrastination prevention/intervention strategies and recommendations" Journal of Developmental Education, 25(Fall), pp 14-24. (2001)

N. Paden, R. Stell: "Reducing procrastination through assignment and course design" Marketing Education Review, 7, pp 17-25. (1997, Summer)

U. Özer, A. Demir, J. R. Ferrari: "Exploring academic procrastination among Turkish students: Possible gender differences in prevalence and reasons" The Journal of Social Psychology, 149(2), pp 241-257. (2009)

M.K. Akinsola, A. Tella: "Correlates of academic procrastination and mathematics achievement of university undergraduate students" Eurasia Journal of Mathematics, Science and Technology Education, 3, pp 363-370. (2007)

G. Elvers, D. Polzella, K. Graetz: "Procrastination in online courses: Performance and attitudinal differences" Teaching of Psychology, 30, pp 159-162. (2003)

S. Moon, A. Illingworth: "Exploring the dynamic nature of procrastination: A latent growth curve analysis of academic procrastination" Personality and Individual Differences, 38, pp 297-309. (2005)

C. Orpen: "The causes and consequences of academic procrastination: A research note" International Journal of Research and Method in Education, 21, pp 73-75. (1998)

Z. Wang, F. Englander: "A cross-disciplinary perspective on explaining student performance in introductory statistics-What is the relative impact of procrastination?" College Student Journal, 44, pp 458-471. (2010)

J.L. Clark, O.W. Hill: Academic procrastination among African-American college student” Psychological Reports, 75, pp 931-936. (1994)

S. Dewitte, H. Schouwenburg: "Procrastination, temptations, and incentives: The struggle between the present and the future in procrastinators and the punctual" European Journal of Personality, 16, pp469-489. (2002)

J.R. Ferrari, S.J. Scher: "Toward an understanding of academic and nonacademic tasks procrastinated by students: The use of daily logs" Psychology in the Schools, 37, pp 359-366. (2000)

B.A. Fritzsche, B.R Young, K.C. Hickson: "Individual differences in academic procrastination tendency and writing success" Personality and Individual Differences, 35, pp 1549-1557. (2003)

E. Lee: "The relationship of motivation and flow experience to academic procrastination in university students" Journal of Genetic Psychology, 166, pp 5-14. (2005)

C. Midgley, T. Urdan: "Academic self-handicapping and performance goals: A further examination" Contemporary Educational Psychology, 26, pp 61-75. (2001) 
A. UzunOzer, B. Demir, J.R. Ferrari: "Exploring academic procrastination among Turkish students: Possible gender differences in Prevalence and Reasons" Journal of Social Psychology, 149, pp241-257. (2009)

J. Sokolowska, A. Zusho: Effective procrastination strategies? Self-regulation of academic procrastination among high achievers. Paper presented at the American Psychological Association Annual Convention, New Orleans. (2006)

A. Lakein: How to get control of your time and your life.New York: Wyden. (1973)

R. S. Schuler: "Managing stress means managing time" Personnel Journal, December, pp851-854. (1979)

R. A. Mackenzie: The time trap: How to get more done in less time, New York, NY:AMACOM. (1972)

R. A. Mackenzie: New time management methods for you and your staff,Chicago, IL: The Dartnell Corporation. (1975)

R. A. Mackenzie: The time trap, New York, NY: AMACOM. (1990)

D. Soucie: "Proper management of your time" CAHPER Journal, 52 (2),pp 36. (1986)

C. Crutsinger: Thinking smarter: Skills for academic success.Carrollton, TX: Brainworks,Inc. (1994)

G. A. Adams, S. M. Jex: "Relationships between time management, control, workfamilyconflict, and strain" Journal of Occupational Health Psychology, 4 (1), pp 72-77. (1999)

T. H. Macan: "Time management: Test of a process model" Journal of Applied Psychology, 79, pp381-391. (1994)

T. H. Macan: "Time-management training: Effects on time behaviors, attitudes, and job performance" The Journal of Psychology, 130, pp229-236. (1996).

T. H. Macan, C. Shahani, R. L. Dipboye, A. P. Phillips: "College students' time management: Correlations with academic performance and stress" Journal of Educational Psychology, 82, pp760-768. (1990)

L.M Hellsten, W. T. Rogers: "Development and preliminary validation of the Time Management for Exercise Scale" Measurement in Physical Education and Exercise Science, 13, pp13-33. (2009)

T. Morris: 101 time smart solutions for teachers, Winnipeg, MB: Portage \& Main Press. (2001)

A. E. Woolfolk, R. L. Woolfolk: "Time management: An experimental investigation" Journal of School Psychology, 24, pp267-275. (1986)

S. M. Puffer: "Task-completion schedules: Determinants and consequences for performance” Human Relations, 42, pp937-955. (1989) 
S. M. Jex, T. C. Elacqua: "Time management as a moderator of relations between stressors and employee strain" Work and Stress, 13, pp182-191. (1999)

B. K. Britton, A. Tesser: "Effects of time-management practices on college grades" Journal of Educational Psychology, 83, pp405-410. (1991)

A. G. Lahmers, C. R. Zulauf: "Factors associated with academic time use and academic performance of college students: a recursive approach" Journal of College Student Development, 41, pp 544-556. (2000)

D. J. Simons, K. M. Galotti: "Everyday planning: An analysis of daily time management" Bulletin of the Psychonomic Society, 30(1), pp 61-64. (1992)

R. L Williams, J. S. Verble, D. E. Price, B. H. Layne, "Relationship between time management practices and personality indices and types" Journal of Psychological Type, 34, pp36-42. (1995)

R. L. Dipboye, A. P. Phillips: “College students' time management: Correlations withacademic performance and stress" Journal of Educational Psychology, 82, pp 760-768. (1990)

C. H. Lay: "Working to schedule on personal projects: An assessment of personobjectcharacteristics and trait procrastination" Journal of Social Behavior and Personality, 5, pp 91-104. (1990)

S. J. Vodanovich, H. M. Seib:RELATIONSHIP BETWEEN TIME STRUCTURE AND PROCRASTINATION. Psychological Reports, 80, 211-215. (1997).

W. Van Eerde: "Procrastination at work and time management training" Journalof Psychology, 137, pp 421-34. (2003)

J. W. Cohen: "Statistical power analysis for the behavioral science" $2^{\text {nd }}$ ed. Hillsdale: NJ. doi: 10.1016/0198-9715(90)90050-4. (1988)

N. K. Malhotra: Marketing Research: An Applied Orientation, $6^{\text {th }}$ ed., pp 246, Prentice Hall. (2009)

H. E. Florey (2000) Retrieved from:https://translate.google.com/translate? $\mathrm{hl}=\mathrm{en} \& \mathrm{sl}=$ auto $\& \mathrm{tl}=\mathrm{en} \& \mathrm{u}=\mathrm{http} \% 3 \mathrm{~A} \% 2 \mathrm{~F} \% 2 \mathrm{Fwww}$. norreg $4 . \mathrm{dk} \% 2 \mathrm{Fstudiefaerd} \%$ 2Findtest01.htm [or] http://faculty.winthrop.edu/stonebrakerr/retention/ UT Learning Cntr/ProcrastinationQuotient.htm [or] http://academics.uafs.edu/ sites/academics.uafs.edu/files/Departments/Academic\%20Success/procrastinatio n_quotient.pdf. 